\title{
Batasan Kewenangan Penyidik Anak Terkait Pelaksanaan Diversi dalam Proses Penyelesaian Perkara Tindak Pidana Anak
}

\author{
Megah Novita Endriyanti ${ }^{1}$, Nurini Aprilianda ${ }^{2}$, Abdul Madjid ${ }^{3}$ \\ ${ }^{1}$ Megah Novita Endriyanti; Fakultas Hukum Universitas Brawijaya; Jl. MT. Haryono No 169; Malang; \\ 65145; Indonesia. \\ ${ }^{2}$ Nurini Aprilianda; Fakultas Hukum Universitas Brawijaya; Jl. MT. Haryono No 169; Malang; 65145; \\ Indonesia. \\ ${ }^{3}$ Abdul Madjid; Fakultas Hukum Universitas Brawijaya; Jl. MT. Haryono No 169; Malang; 65145; \\ Indonesia.
}

\section{AR T I C L E IN FO}

Article history:

Received 2018-08-12

Received in revised form

2018-10-14

Accepted 2018-12-01

Kata kunci: Batasan Kewenangan, Penyidik Anak, Diversi.

Keywords: Boundaries of Authority, Juvenile Investigators, Divertion.

\section{Abstrak}

Tulisan ini bertujuan untuk menganalisis terkait batasan kewenangan penyidik Anak terkait dengan pelaksanaan diversi dalam proses penyelesaian perkara tindak pidana Anak. Untuk menjawab tujuan tulisan tersebut, digunakan penelitian hukum normatif, dengan menggunakan pendekatan perundang-undangan dan kasus. Hasil penelitian tersebut menunjukkan bahwa penyidik Anak dalam penyelesaian perkara tindak pidana Anak dapat menerapkan diskresi terkait dengan pelaksanaan diversi. Adapun batas kewenangan diskresi penyidik Anak yaitu alasan dari dilaksanakan diversi yang tidak memenuhi syarat pelaksanaannya dalam UU SPPA harus logis dan masuk akal, tidak untuk tindak pidana berat seperti tindak pidana terhadap tubuh dan nyawa, serta bukan tindak pidana pengulangan. Dalam hal kasus pencurian dengan pemberatan yang hasil diversinya sudah ditetapkan oleh Ketua Pengadilan Negeri Kota Pasuruan, diskresi diambil oleh kepolisian dengan berbagai pertimbangan. Salah satunya yaitu karena pihak pelaku dan pihak korban sepakat untuk kasus tersebut diselesaikan secara kekeluargaan karena ternyata pelaku masih memiliki hubungan persaudaraan dengan korban. Maka dari itu, dengan beberapa kesepakatan pihak korban memutuskan untuk menyelesaikan perkara tersebut diluar proses peradilan, yaitu diversi.

\section{Abstract}

This paper aims to analyze the limits of the authority of the child investigator related to the implementation of diversion in the process of resolving cases of child crimes. To answer the purpose of this paper, normative legal research is used, using the legal approach and case. The results of the study indicate that child investigators in solving cases of child crimes can apply discretion related to the implementation of diversion. The authority limit for discretion of child investigators, namely the reason for implementing diversion that does not fulfill the implementation re-

Corresponding Author:

Megah Novita Endriyanti

E-mail address: megahnovitaendriyanti@yahoo.co.id 
quirements in the SPPA Law, must be logical and reasonable, not for serious crimes such as criminal acts against the body and life, and not repetitive crimes. In the case of theft with weights, the results of which have been determined by the Chairperson of the Pasuruan City District Court, discretion is taken by the police with various considerations. One of them is because the perpetrators and the victims agreed that the case would be settled in a family manner because the perpetrator still had a brotherly relationship with the victim. Therefore, with several agreements the victims decided to settle the case outside the court process, namely diversion.

\section{Latar Belakang}

Anak merupakan salah satu aset berharga yang dimiliki setiap Negara. Masa depan suatu Negara ditentukan oleh Anak sebagai generasi penerusnya, sebagai generasi yang akan meneruskan cita-cita bangsa dan menciptakan kemajuankemajuan di masa yang akan datang. Setiap Negara juga memiliki peraturan perundang-undangan guna mengatur dan mengontrol masyarakatnya. Itulah mengapa setiap Negara sudah pasti memiliki peraturan perundang-undangan yang khusus mengatur tentang anak, dimulai dari perlindungan anak yang merupakan sekumpulan hak-hak yang diperoleh oleh anak dan harus dipenuhioleh Negara dan peraturan perundang-undangan yang mengatur bagaimana menangani anak yang sedang berhadapan dengan hukum.

Anak baik di Indonesia maupun di seluruh dunia ketika berhadapan dengan hukum, bukan hanya duduk sebagai korban, namun ada kalanya juga sebagai pelaku yang berkonflik dengan hukum. Pada dasarnya anak harus dilindungi dan ditumbuhkembangkan di lingkungan yang baik karena setiap pola tingkah laku orang-orang di sekitarnya dijadikan contoh oleh anak dalam berperilaku. Itulah mengapa pentingnya pendidikan untuk anak sejak usia dini, agar mereka tumbuh menjadi seseorang dengan moral yang baik dan terdidik.

Indonesia telah mengatur ketentuan tentang proses penyelesaian perkara pidana yang dilaku- kan oleh anak untuk pertama kalinya yaitu bersamaan dengan berlakunya KUHP di Indonesia. KUHP mengatur tentang seseorang yang belum dewasa yang melakukan tindak pidana dengan Pasal 45, 46 dan 47. Pada tahun 1997 Indonesia menerbitkan Undang-undang Negara Republik Indonesia Nomor 3 Tahun 1997 tentang Pengadilan Anak Lembaran Negara Republik Indonesia Tahun 1997 Nomor 3668 yang selanjutnya disebut dengan UU Pengadilan Anak, yang kemudian dengan lahirnya UU Pengadilan Anak tersebut, Pasal 45, 46 dan 47 KUHP yang digunakan untuk menyelesaikan perkara pidana anak dinyatakan tidak berlaku dan dihapus. Undang-undang tersebut mengatur tentang proses penanganan anak yang terjerat kasus tindak pidana. Dalam UU Pengadilan Anak, anak yang sedang menjalani proses pemeriksaan perkara disebut anak nakal yang mana hal tersebut dinilai minimbulkan stigmatisasi bagi anak.

Hingga pada tahun 2012, karena UU Pengadilan Anak dinilai sudah berjalan tidak efektif karena berdampak buruk bagi anak di mata masyarakat karena timbulnya stigmatisasi dan banyak memunculkan recidivist anak, maka diterbitkanlah pembaharuan dari UU Pengadilan Anak tersebut, yaitu Undang-Undang Negara Republik Indonesia Nomor 11 Tahun 2012 tentang Sistem Peradilan Pidana Anak, Lembaran Negara Republik Indonesia Tahun 2012 Nomor 153, Tambahan Lembaran Negara Republik Indonesia Nomor 5332 yang selanjutnya dibaca UU SPPA. 
Pembaharuan dalam UU SPPA mengusung konsep restorative justice,yaitu suatu upaya untuk mengembalikan anak ke masyarakat seperti keadaan semula sebelum terjadi tindak pidana. Untuk mewujudkan upaya tersebut, dalam pembaharuan UU SPPA ini dikenal hal baru, yaitu diversi yang diatur pada pasal 6 sampai pasal 15, diversi ini merupakan proses penyelesaian perkara tindakan pelanggaran hukum yang terjadi yaitu dengan cara mempertemukan pihak korban serta keluarga dan pihak pelaku serta keluarga untuk duduk bersama guna membicarakan proses penyelesaian perkara secara kekeluargaan. Pada pertemuan tersebut, penyidik anak selaku mediator memberikan kesempatan kepada pelaku untuk menjelaskan seputar gambaran-gambaran mengenai kejadian tindak pidana yang telah dilakukannya. (Marlina, 2009)

Diversi diatur dalam Pasal 6 sampai dengan Pasal 15 UU SPPA. Diversi sendiri lebih dikenal sebagai suatu upaya untuk mengalihkan anak dari proses hukum formal ke proses hukum informal guna menghindarkan anak dari proses hukum yang dapat mengganggu mental dan psikisnya. Setiap tingkat proses hukum mulai dari penyidikan, penuntutan sampai pemeriksaan di pengadilan wajib untuk diupayakan Diversi. Diversi tidak serta merta dilaksanakan pada semua kasus anak, namun pada Pasal 7 ayat (2) UU SPPA yang berbunyi: "Diversi sebagaimana dimaksud pada ayat (1) dilaksanakan dalam hal tindak pidana yang dilakukan: Diancam dengan penjara di bawah 7 (tujuh) tahun; dan Bukan merupakan pengulangan tindak pidana." (Pasal 7 ayat (2) UU SPPA)

Namun, pada faktanya pelaksanaannya tidaklah sesuai dengan yang tertera di peraturan perundang-undangan. Contohnya yaitu penyidik di Kepolisian Resort Pasuruan Kota yang selanjutnya disebut Polresta Pasuruan, masih mengupayakan diversi terhadap beberapa kasus tindak pidana yang memuat ancaman diatas 7 (tujuh) tahun, tindak pidana kesusilaan contohnya. Tindak pidana kesusilaan yang paling sering terjadiya itu tindak pidana perkosaan dan pencabulan sebagaimana diatur pada pasal 285 dan 289 Kitab UndangUndang Hukum Pidana yang selanjutnya disebut KUHP memuat ancaman pidana penjara 12 dan 9 tahun. Jika dikaitkan dengan Pasal 7 ayat (2) UU SPPA, tindak pidana kesusilaan tersebut tidak dapat diupayakan diversi karena ancaman pidananya diatas 7 (tujuh) tahun penjara. Penyidik Polresta Pasuruan tetap mengupayakan diversi terhadap tindak pidana kesusilaan yang dilakukan oleh Anak dengan berbagai pertimbangan.

Bukan hanya tindak pidana kesusilaan, namun juga tindak pidana lain yang juga memuat ancaman pidana lebih dari 7 (tujuh) tahun, yaitu tindak pidana pencurian dengan pemberatan yang diatur dalam Pasal 363 KUHP yang berbunyi:

“Diancam dengan pidana penjara paling lama tujuh tahun: Pencurian ternak; Pencurian pada waktu terjadi kebakaran, letusan, banjir, gempa bumi atau gempa laut, gunung meletus, kapal keram, kapal terdampat, kecelakaan kereta api, huru-hara, pemberotakan atau bahaya perang; Pencurian pada waktu malam hari dalam sebuah rumah atau di pekarangan tertutup yang ada rumahnya, yang dilakukan oleh orang yang yang ada di situ tanpa diketahui atau tanpa dikehendaki oleh yang berhak; Pencurian yang dilakukan oleh dua orang atau lebih dengan bersekutu; Pencurian yang untuk masuk ke tempat melakukan kejahatan, atau untuk dapat mengambil barang yang hendak dicuri itu, dilakukan dnegan merusak, memotog atau memanjat, atau dengan memakai anak kunci palsu, perintah palsu atau pakaian jabatan palsu. Bila pencurian tersebut dalam nomor 3 disertai dengan salah satu hal dalam nomor 4 dan 5, maka perbautan itu diancam dengan pidana penjara paling lama sembilan tahun." (Pasal 363 KUHP)."

Proses diversi terhadap Anak yang melakukan tindak pidana sesuai dengan pasal 363 (1) ke4 (empat) KUHP menghasilkan kesepakatan diversi. Sesuai dengan prosedur yang ditetapkan 
oleh UU SPPA jika upaya diversi yang dilakukan menghasilkan suatu kesepakatan, maka kemudian penyidik harus segera mengirimkan hasil kesepakatan diversi tersebut untuk dimintakan ketetapan diversi kepada ketua Pengadilan Kota Pasuruan. Lain halnya dengan hasil kesepakatan diversi untuk tindak pidana kesusilaan yang ditolak oleh Ketua Pengadilan Negeri Pasuruan karena dianggap tindak pidana kesusilaan tidak diperbolehkan diupayakan diversi karena memuat ancaman lebih dari 7 (tujuh) tahun penjara, berbeda dengan tindak pidana pencurian pemberatan yang juga memuat ancama pidana penjara 7 (tujuh) tahun penjara, namun Ketua Pengadilan Negeri Pasuruan tetap menerbitkan penetapannya dengan Penetapan Pengadilan Negeri Kota Pasuruan Nomor: 01/ Pid Sus_Anak/2014/PN.Psr tertanggal 24September 2014.

Permasalahan dalam penelitian ini yaitu apakah batasan kewenangan penyidik Anak terkait dengan pelaksanaan diversi dalam proses penyelesaian perkara tindak pidana Anak

\section{Metode}

Kajian ini menggunakan pendekatan perundang-undangan (statute approach) dan pendekatan kasus (case approach). Pendekatan perundang-undangan digunakan untuk meneliti Undang-undang Sistem Peradilan Pidana Anak, sedangkan pendekatan kasus menggunakan penetapan hakim dalam kasus Anak.

Bahan hukum yang berhasil dikumpulkan akan dideskripsikan dengan ditambahkan argumentasi-argumentasi dari peneliti secara utuh dalam artian uraian apa adanya terhadap suatu kondisi atau posisi dari preposisi-preposisi hukum atau non-hukum. Teknik ini kemudian dilanjutkan dengan langkah analisis. Analisis yang dimaksud yaitu analisis yang bersifat evaluatif, dalam artian melakukan evaluasi, juga melakukan interpretasi, dalam artian menjelaskna/menafsirkan norma yang memuat ketentuan sistem peradilan pidana anak.
Teknik interpretasi yang akan digunakan dalam tesis ini yaitu diantaranya interpretasi gramatikal, interpretasi sistematis, dan interpretasi kontekstual.

\section{Pembahasan}

Pembaharuan dalam sistem peradilan pidana anak bukan hanya meliputi konsep keadilan restoratif dengan asas-asas yang mengedepankan kepentingan terbaik untuk anak dan menghindarkan anak dari proses peradilan, namun juga adanya upaya diversi yang mana upaya tersebut ditawarkan di setiap tingkatan proses penyelesaian perkara pidana anak untuk mencapai tujuan dari pembaharuan sistem peradilan pidana anak yang utama yaitu menghindarkan anak dari proses peradilan pidana.

Diversi pada kasus-kasus anak yang berhadapan dengan hukum menjadi jalan keluar yang cukup menentukan bagi anak. Upaya diversi yang juga dicantukmkan dalam The Beijing Rules akan memberi jaminan bahwa anak mendapat resosialisasi dan reedukasi tanpa harus menanggung stigmatisasi.

Kepolisian sebagai pintu gerbang dari sistem peradilan pidana anak dan pihak yang berwenang pertama kali untuk menentukan posisi seorang anak yang berhadapan dengan hukum, menyisakan banyak tempat dalam ingatan anak yang berhadapan dengan hukum. Guna kepentingan penyidikan, polisi melakukan penangkapan, panahanan, penggeledahan, perampasan barang dan tindakan lain sesuai dengan KUHAP. Proses penyelidikan kasus kejahatan dapat diumpamakan sebagai serangkaian pintu masuk dimana tindakan evaluasi dan penilaian tertentu harus dibuat sebelum memasuki pintu tersebut. (Prakoso, 2016)

Undang-Undang POLRI menyebutkan bahwa: Setiap pejabat Kepolisian Negara Republik Indonesia memiliki kewenangan diskresi, yaitu kewenangan untuk bertindak demi kepentingan 
umum berdasarkan penilaian sendiri. Sama halnya dengan kasus yang terjadi di Kota Pasuruan. Pada hari Minggu, tanggal 07 September 2014 sekira pukul 17.30 WIB, telah terjadi tindak pidana pencurian sepeda motor milik JA dengan terdakwa MK. Kronologi kejadian dimulai pada hari yang sama yaitu tepatnya pukulnya $14.00 \mathrm{WIB}$, JA mengunjungi salah satu rental di pasar Kebonagung, Kecamatan Purworejo, Kota Pasuruan dengan menggunakan sepeda motor Yamaha Vixion berwarna putih. JA memarkirkan sepeda motornya seperti biasa di depan rental tersebut dan meninggalkan sepeda motornya dalam keadaan dikunci setir. Kemudian JA masuk ke dalam rental bersama saksi, JA mengaku sempat melihat sepeda motornya pada pukul $15.00 \mathrm{WIB}$, hingga pukul 17.30 saat JA hendak pulang, sepeda motornya yang terparkir di depan rental sudah tidak ada di tempat. Akibat kejadian tersebut JA mengalami kerugian sebesar Rp. 23.000.000,- (dua puluh tiga juta rupiah).

Setelah diadakan serangkaian penyelidikan dan penyidikan, kepolisian berhasil menangkap MK sebagai tersangka kasus pencurian sepeda motor JA. Melalui penyelidikan diketahuilah bahwa MK masih berusia 16 tahun 9 bulan yang mana dalam sistem peradilan pidana MK tergolong masih dibawah umur. Kasus ini kemudian dilimpahkan kepada Unit Pelayanan Perempuan dan Anak untuk dilakukan penyidikan hingga proses selanjutnya. MK didakwa dengan Pasal 363 ayat (2) KUHP tentang pencurian dengan pemberatan.

Upaya hukum diversi tidak serta merta dilakukan terhadap setiap kasus. Terdapat syaratsyarat yang harus dipenuhi, syarat pelaksanaan diversi dimuat dalam Pasal 7 ayat (2) UU SPPA. Terdapat dua syarat dalam pasal tersebut, yaitu syarat subyektif dan syarat obyektif. Syarat subyektif dalam pasal tersebut yaitu yang berkaitan dengan pelaku, yaitu tindak pidana yang dilakukan Anak tersebut bukanlah suatu pengulangan, yang artinya Anak harus benar-benar melakukan tindak pidana tersebut untuk yang pertama kalinya, baik untuk tindak pidana yang sama maupun tidak pidana yang lain.

Syarat obyektif pada pasal 7 ayat (2) UU SPPA tersebut yaitu berkaitan dengan tindak pidana yang dilakukan oleh Anak, yaitu tindak pidana yang dilakukan oleh Anak tersebut tidak boleh memuat ancaman lebih dari 7 (tujuh) tahun perjara seperti pembunuhan, pelanggaran kesusilaan dan tindak pidana lain yang memuat ancaman lebih dari 7 (tujuh) tahun penjara. (Pramukti dkk, 2015) Setelah dilakukan upaya diversi, penyidik menentukan langkah selanjutnya yaitu jika upaya diversi tersebut menghasilakan kesepakatan maka penyidik segera membuat berita acara diversi yang menyebutkan juga kesepakatan-kesepakatan yang sudah disepakati oleh pihak keluarga Anak Korban beserta pihak keluarga Anak kepada Ketua Pengadilan Negeri setempat guna dimintakan Surat Penetapan Diversi yang kemudian Surat Penetapan Diversi itulah yang menjadi dasar untuk penyidik membuat Surat Perintah Pemberhentian Penyidikan yang artinya perkara selesai dengan jalur kekeluargaan. Penyidik akan membuat berita acara Diversi dan melimpahkan perkara ke Kejaksaan guna dilakukan proses selanjutnya yaitu penuntutan jika upaya diversi tersebut gagal atau tidak menemukan titik temu dan tidak menghasilkan kesepakatan antara kedua belah pihak yang sedang berperkara.

Sistem peradilan pidana Anak dimulai dari penyelidikan, yaitu suatu serangkaian tindakan penyelidikan yang dilakukan oleh penyelidik guna mencari bukti-bukti dan saksi-saksi atas sebuah laporan, razia, atau tertangkap tangan suatu kejadian yang diduga suatu tindak pidana. Jika sudah menemukan bukti-bukti dan saksi yang cukup, serta menemukan tersangka, maka proses selanjutnya yaitu naik satu tingkat menjadi penyidikan. Penyidikan masih tetap berada di bawah kewenangan Kepolisian Negera Republik Indonesia yang diberi kewenangan untuk melakukan serangkaian tindakan penyidikan. (Gultom, 2009). 
Penentuan tersangka sebelumnya berada dalam proses penyelidikan, termasuk identitas tersangka, itu artinya usia pelaku juga sudah dapat diketahui sejak akan dimulainya proses penyidikan. Jika dalam penyelidikan sudah diketahui bahwa usia pelaku masih di bawah 18 tahun, maka penyidikan dilimpahkan kepada Unit Pelayanan Perempuan dan Anak, yang mana pada unit tersebut khusus menangani semua perkara tentang perempuan dan Anak.

Pelaku yang masih berusia kurang dari 18 tahun dilakukan penyidikan di bawah Unit Pelayanan Perempuan dan Anak, yang mana di dalam unit tersebut terdiri dari beberapa Penyidik yang khusus ditunjuk dan diberi kewenangan untuk menanagani perkara-perkara Anak yang dalam UU SPPA disebut sebagai Penyidik Anak.

Seperti yang sudah dijelaskan, terdapat beberapa syarat yang harus dipenuhi sebelum kasus yang melibatkan Anak dilakukan diversi. Seperti pada Surat Penetapan Diversi No: 01/Pid.Sus_ Ank/2014/Pn. Psr tentang kasus pencurian dengan pemberatan yang memenuhi Pasal 363 (2), meninjau dari pasal yang dilanggar, pasal tersebut memuat ancaman 9 tahun penjara yang mana berarti kasus dengan pasal tersebut tidak dapat dilakukan diversi.

Namun, saat penyidik Anak meminta saran kepada Bapas, tidak sepenuhnya laporan tersebut akan dilakukan oleh Penyidik Anak. Pada kasus tersebut, biasanya Bapas akan merekomendasikan untuk melanjutkan kasus tersebut ke tingkat selanjutnya, yaitu penuntutan. Karena pasal tersebut tidak dapat diupayakan diversi menurut UUSPPA karena memuat ancaman penjara lebih dari 7 (tujuh) tahun. Berdasarkan hasil dari serangkaian proses penyidikan yang dilakukan oleh penyidik, penyidik menilai dalam kasus tersebut masih dapat diupayakan diversi karena ternyata antara pelaku dengan korban masih memiliki hubungan persaudaraan. Selain itu, barang bukti yang berupa sepeda motor milik korban yang dicuri oleh Anak masih ada dan dalam artian belum dipindah tangankan atau dijual.

Ditambah, dari pihak korban telah setuju untuk menyelesaikan perkara tersebut melalui jalur kekeluargaan, dan meminta kasus ditutup dan barang bukti dikembalikan kepada pihak korban, maka upaya diversi pun dilaksanakan oleh penyidik dengan menghadirkan pihak pelaku beserta keluarga, pihak korban beserta keluarga, penyidik, serta Bapas.

Diversi yang dilakukan oleh penyidik telah melanggar ketentuan yang ada pada UU SPPA yaitu tepatnya pada pasal 7 ayat (2), hal tersebut membuktikan bahwa pada UU SPPA masih terdapat celah untuk dilanggar oleh aparat penegak hukum, dengan begitu tujuan dibuatnya peraturan perundang-undangan tentang sistem peradilan pidana anak yang salah satunya adalah untuk menjamin kepastian hukum mengenai pengaturan penyelesaian perkara tindak pidana yang dilakukan oleh Anak belum terpenuhi.

Penyidik dalam kasus ini menilai bahwa tindak pidana yang dilakukan pelaku merupakan tindak pidana yang pertama kali dilakukannya, ditambah fakta bahwa ternyata pihak korban masih memiliki hubungan persaudaraan dengan pelaku, maka atas kesepakatan bersama, pihak korban dan pihak pelaku setuju untuk menyelesaikan perkara tersebut secara kekeluargaan. Barang bukti milik korban juga masih dalam kuasa pelaku, yang mana dalam kesepakatan tersebut korban juga meminta agar barang bukti dikembalikan kepada korban dan dengan begitu korban sudah merasa mendapatkan keadilan.

Diversi yang dilakukan oleh penyidik memang menunjukkan bahwa UUSPPA masih belum memenuhi kepastian hukum terkait pada pasal 7 ayat (2) karena dalam pasal tersebut tidak memberikan celah atau kesempatan kepada penyidik, penuntut umum dan hakim untuk memilih apakah harus tetap mematuhi isi pasal tersebut atau mengijinkan aparat penegak hukum untuk melakukan 
hal diluar yang diatur menurut penilaiannya sendiri, khususnya kepada penyidik yang dalam sistem peradilan pidana anak digunakan sebagai pihak yang paling awal menangani kasus tindak pidana yang dilakukan oleh Anak dan saat dilakukan proses penyelidikan dan penyidikan berhadapan secara langsung dengan pihak korban maupun pihak pelaku, dengan begitu penyidiklah yang mengetahui apa sebenarnya yang diinginkan oleh korban dan pelaku. Namun di sisi lain, dengan tidak terpenuhinya fungsi kepastian hukum dalam pasal ini, terdapat fungsi hukum lain yang sudah terpenuhi yaitu keadilan. Adil bagi korban yang menginginkan untuk menyelesaikan perkaranya secara kekeluargaan dan adil bagi Anak ketika ia sudah menyesali perbuatannya, berjanji untuk tidak mengulangi perbuatannya dan bersedia mengembalikan barang bukti milik korban.

Diskresi merupakan suatu tindakan atau kebijakan yang diambil oleh Kepolisian khususnya penyidik, yang pada umumnya bertentangan dengan peraturan perundang-undangan yang bertujuan untuk mengutamakan kepentingan umum dan bermanfaat. Diskresi juga merupakan suatu jalan keluar yang dapat diambil oleh penyidik untuk melakukan suatu upaya penyelesaian perkara yang tidak diatur atau bahkan bertentangan dengan peraturan perundang-undangan selama upaya tersebut bertujuan untuk keadilan. Untuk menentukan menentuka kewenangan diskresi kepolisian, baik menentukan batas-batas kewajiban dan sekaligus untuk membatasi tindakan-tindakan kepolisian, maka harus memperhatikan asas-asas kewenangan diskresi kepolisian, khususnya terhadap tindakan represif maupun preventif. Asas ini merupakan sus asas dari asas-asas kewajoiban, dan polisi harus dapat menilai sendiri secara pribadi. Penilaian sendiria itu masih terikat dalam lingkungan kewajibannya. (Prakoso, 2010)

Penyelesaian perkara tindak pidana Anak, mengingat UU SPPA bertujuan menghindarkan Anak dari proses system peradilan pidana Anak, maka diskresi dapat dilakukan selama tunjuannya untuk menghindarkan Anak dari proses peradilan pidana Anak.

Pasal 18 Undang-Undang Nomor 2 Tahun 2002 tentang Kepolisian Negara Republik Indonesia yang selanjutnya disebut UU POLRI mengatur tentang diskresi kepolisian. Pasal 18 ayat (1) tidak menyebut kata "diskresi" secara jelas, namun menggunakan istilah "bertindak menurut penilaiannya sendiri". Adapun syarat pelaksanaan diskresi itu sendiri diatur pada ayat (2), pasal tersebut menegaskan bahwasanya diskresi bukanlah suatu kewenangan yang dimiliki oleh kepolisian, namun diskresi itu adalah suatu tindakan oleh kepolisian yang harus dipertanggungjawabkan bedasarkan hukum dan norma yang berlaku. Itulah sebabnya, untuk mengurangi menyalahgunaan dan penyimpangan, diskresi kepolisian haruslah diberi batasan dan pengawasan. Batasan yang diberikan haruslah sesuai dengan tujuan adanya hukum pidana yaitu untuk melindungi kepentingan umum, jadi diskresi kepolisian dapat dilakukan hanya atas dasar pertimbangan kepentingan umum.

Satu aspek yang paling penting dalam pengambilan diskresi yaitu pertanggung jawaban. Pertanggungjawaban itu sediri menyangkut aspek hukum, etik dan disiplin. Dan pada dasarnya, diskresi yang dilakukan oleh kepolisian yaitu timbul karena adanya kekosongan hukum dan masyarakat berkembang lebih pesat mendahului aturan sehingga untuk mengatasi hal tersebut kepolisian melakukan diskresi. Jadi, diskresi disini bertujuan untuk mengsi kekosongan hukum bukan untuk menggantikan hukum.

Sistem peradilan pidana Indonesia menempatkan kepolisian di jajaran paling depan, yaitu penyelidikan dan penyidikan. Merupakan tugas dari kepolisian untuk mempertimbangankan kasus mana yang pantas untuk diajukan ke pengadilan. Dalam artian, tidak semua perkara yang masuk dapat diajukan ke pengadilan, dan tugas kepolisanlah utnuk menyeleksi perkara-perkara tersebut. 
Karena jika tidak, akan terjadi penumpukan perkara di pengadilan yang akan menimbulkan ketidak efisienan bagi semua pihak. Itulah sebabnya pertimbangan kepolisian dianggap sangat penting.

Tidak ada penjelasan secara rinci tentang apa itu diskresi, tindakan-tindakan apa saja yang termasuk dalam diskresi, dan jenis-jenis diskresi kepolisian, yang diatur hanyalah sebatas pedoman atau syarat-syarat dalam mengambil keputusan untuk dilakukannya diskresi kepolisian, syarat tersebut diatur pada Pasal 16 ayat (2) UU POLRI, itupun sebatas diskresi yang dilakukan di tingkat penyelidikan, yang mana pasal tersebut dapat dilakukan dalam hal terjadi suatu peristiwa pidana dan terdapat seseorang yang diduga telah melakukannya, dan penyelidik harus segera melakukan tugasnya tanpa surat perintah.

Seperti yang telah disebutkan diatas, diskresi kepolisian tidak disebutkan secara gamblang menggunakan istilah "diskresi" namun disebut dengan sebutan "bertindak menurut penilaiannya sendiri" seperti yang disebutkan pada Pasal 18 UU POLRI yang berbunyi: Untuk kepentingan umum, pejabat Kepolisian Negara Republik Indonesia dalam melaksanakan tugas dan kewenangannya dapat bertindak menurut penilaiannya sendiri; Pelaksanaan ketentuan sebagaimana dimaksud dalam ayat (1) hanya dapat dilakukan dalam keadaan yang sangat perlu dengan memperhatikan peraturan perundnag-undangan, serta Kode Etik profesi Kepolisian Negara Republik Indonesia.

Jadi, menurut pasal tersebut diskresi dapat dilakukan oleh penyidik hanya dengan pertimbangan yang bertujuan untuk kepentingan umum. Diskresi tidak boleh dilakukan jika hanya bertujuan untuk kepentingan penyidik sendiri. Dalam sistem peradilan pidana anak contohnya, jika UU SPPA mengatur syarat tertentu untuk dilakukannya upaya diversi, hendaknya penyidik tetap mematuhi aturan tersebut guna tercapainya kepastian hukum UU SPPA tersebut.
Namun sekali lagi, karena penyidik yang berhadapan langsung dengan pihak korban dan pihak pelaku yang mana penyidik dianggap lebih mengerti apa yang diinginkan oleh pihak korban dan apa yang dirasakan oleh pelaku, dan juga dalan UU SPPA juga disebutkan asas yang mendasari UU SPPA ini salah satunya yaitu mengedepankan kepentingan terbaik untuk Anak sesuai pasal 2 UU SPPA, itulah sebabnya berdasarkan penilaiannya, penyidik dapat mengambil diskresi untuk melakukan diversi terhadap kasus-kasus tertentu dengan berbagai pertimbangan yang masuk akal logis dan tetap tidak boleh bertentangan dengan kepentingan umum dan tetap mengutamakan kepentingan terbaik untuk anak. Juga mengingat konsep Restorative Justice yang mana konsep tersebut berusaha sedapat mungkin untuk menghindarkan anak dari proses penyelesaian perkara pidana formal yang dapat menimbulkan stigmatisasi yang dapat menggangu psikis dan mental anak yang berpengaruh pada masa depannya.

Diskresi dalam hal melaksanakan diversi diluar syarat yang ditentukan dalam pasal 7 ayat (2) UU SPPA juga tidak dapat dilakukan pada semua tindak pidana yang memuat ancaman penjara lebih dari 7 (tujuh) tahun, seperti pembunuhan, pencabulan atau tindak pidana berat lainnya yang berhubungan dengan tubuh dan nyawa, karena kepentingan umum juga tak menghendaki kasus tersebut diselesaikan dengan jalur kekeluargaan dan anak dikembalikan kepada orang tua dan kembali bebas berkeliaran di masyarakat yang mana hal tersebut akan menimbulkan ketidak nyamanan di masyarakat. Anak yang sudah melakukan perbuatan pidana berat terhadap tubuh dan nyawa harus dididik dam dibimbing oleh Negara dan diberika efek jera dengan pidana agar tidak terulang di masa depan.

Diskresi penyidik dalam melaksanakan diversi diluar ketentuan Pasal 7 ayat (2) UU SPPA juga tidap dapat dilakukan terhadap tindak pidana 
pengulangan. Karena pada dasaranya, bisa jadi tindak pidana sebelumnya sudah dilakukan diversi dan berhasil, namun ketika kesepakatan sudah dilakukan, anak kembali mengulangi tindak pidana baik tindak pidana yang sama maupun berbeda, artinya anak tersebut belum merasa jera dengan apa yang sudah dilakukannya sebelumnya, dan untuk memberi efek jera terhadap anak tersebut, penyidik tidak boleh memberikan diskresinya untuk dilakukan diversi, dan segera melanjutkan perkara ke proses selanjutnya yaitu penuntutan, agar Anak segera diproses di persidangan dan mendapatkan sanksinya. Dengan begitu, anak akan belajar dan berfikir untuk tidak melakukan perbuatan pidana kembali di kemudian hari.

Dalam hal kasus pencurian dengan pemberatan yang hasil diversinya sudah ditetapkan oleh Ketua Pengadilan Negeri Kota Pasuruan, diskresi diambil oleh kepolisian dengan berbagai pertimbangan. Salah satunya yaitu karena pihak pelaku dan pihak korban sepakat untuk kasus tersebut diselesaikan secara kekeluargaan karena ternyata pelaku masih memiliki hubungan persaudaraan dengan korban. Maka dari itu, dengan beberapa kesepakatan pihak korban memutuskan untuk menyelesaikan perkara tersebut diluar proses peradilan, yaitu diversi.

Diversi yang dilakukan oleh penyidik dalam kasus tersebut dapat dikatakan melanggar ketentuan UU SPPA namun tidak melanggar ketentuan pada pasal 18 UU POLRI yang mengatur tentang tujuan dilakukannya diskresi oleh kepolisian. Diversi dilakukan karena yang pertama, pihak keluarga korban dan pihak keluarga pelaku setuju agar perkara tersebut diselesaikan secara kekeluargaan, karena ternyata kedua belah pihak masih terikat hubungan persaudaraan yang mana pihak keluarga korban tidak menghendaki pelaku untuk dipidana mengingat untuk kepentingan masa depan pelaku dan menjaga nama baik keluarga. Yang kedua, barang bukti yang berupa sepeda motor milik korban juga masih ada dan korban meminta untuk cukup mengembalikan sepeda motor tersebut, dan yang ketiga tindak pidana pen- curian yang dilakukan oleh pelaku tersebut merupakan pertama kalinya.

\section{Simpulan}

Berdasarkan pemaparan tersebut, disimpulkan bahwa kewenanga kepolisian atau penyidik anak dalam hal diskresi untuk melakukan diversi yang mana tindak pidana yang dilakukan oleh anak tidak memenuhi syarat yang tercantum dalam Undang-undang Sistem Peradilan Pidana Anak khususnya pada pasal 7 ayat (2) yaitu alasan yang diambil haruslah logis dan masuk akal, terutama tetap harus mengedepankan asas kepentingan terbaik bagi anak dan mneghindarkan anak dari proses pidana, tindak pidana yang dilakukan oleh anak bukan merupakan tindak pidana terhadap tubuh dan nyawa, dan bukan merupakan pengulangan.

Kesesuaian antara peraturan perundangundangan yang diatur dengan implementasi haruslah sama. Sehingga kemungkinan untuk diambil langkah diskresi oleh penyidik menjadi kecil. Diharapkan para pembuat peraturan perundangundangan dapat memperbaiki undang-undang sistem peradilan pidana anak karena ternyata sejak diberlakukan pada tahun 2014, 4 tahun berlalu masih terdapat banyak permasalahan terkait penyidikan khususnya diversi. Mengingat UU SPPA merupakan pedoman utama untuk menyelesaikan tindak pidana yang dilakukan oleh anak, yang mana undang-undang tersebut diharapkan tidak boleh terdapat kekurangan sedikit pun karena yang dipertaruhkan dalam implementasinya yaitu Anak.

\section{Daftar pustaka}

Gultom, Maidin. 2009. Perlindungan Hukum terhadap Anak dalam Sistem Peradilan Pidana Anak di Indonesia. Jakarta. Refika Aditama.

Prakoso, Abintoro. 2016. Pembaharuan Sistem Peradilan Pidana Anak. Yogyakarta. Aswaja Pressindo. 
Prakoso, Djoko. 2010. Polri sebagai Penyidik dalam Penegakan Hukum. Jakarta. Bina Aksara.

Pramukti, Angger Sigit dan Fuady Primaharsya, 2015. Sistem Peradilan Pidana Anak. Yogyakarta. Pustaka Yusitisia.

Undang-Undang Republik Indonesia Nomor 11 Tahun 2012 tentang Sistem Peradilan Pidana Anak. 30 Juli
2012. Lembaran Negera Republik Indonesia Tahun 2012 Nomor 153. Tambahan Lembaran Negara Republik Indonesia Tahun 2012 Nomor 5332. Jakarta.

Undang-Undang Republik Indonesia Nomor 2 Tahun 2002 tentang Kepolisian Negara Republik Indonesia. 8 Januari 2002. Lembaran Negara Republik Indonesia Tahun 2002 Nomor 2. Jakarta. 